\title{
Rethinking the private hypothesis: Epistolary topographies in Carrington's letters
}

Maria Tamboukou, Centre for Narrative Research, University of East London.

Abstract: In this paper I look into the letters of Dora Carrington, a British artist who lived and worked in the first half on the 20th century in the UK. I am particularly interested in her life-long interest in decorating private spaces and making delightful illustrations of them in her letters. Carrington's long-life interest in turning lived spaces into works of art went hand in hand with her overall disillusionment with her paintings. The paper discusses the problem of why a young woman artist in the peripheries of the Bloomsbury group had difficulties in devoting herself to her art. This problem I argue has to be considered within what drawing on Foucault I have called the private hypothesis, the long held argument that the private has been socially constructed and experienced as 'a space' for women. My argument is that for Carrington as for many of her contemporaries it was not the access to the public but the negotiation of solitude and privacy that emerges as a problem. Carrington's love and passion for private spaces and her epistolary topographies are expressions of spatial technologies of the female self: an artistic intervention in reclaiming solitude and privacy and in reinventing herself.

Lying in bed I've come to a great many conclusions: one is I shall paint all the wood work in my room pale-yellow-green, only so pale, it will be the colour of the calyx of a primrose and on the walls I shall frame, in pale yellow wood frames, my new pictures of birds that Margaret Waley sent me yesterday. ${ }^{1}$

In February 1927, this is how Dora Carrington (1893-1932), a British artist in the peripheries of the Bloomsbury group, ${ }^{2}$ was visualizing her bedroom in a letter to her friend Gerald Brenan. Throughout her life, Carrington passionately loved her houses and spent a good deal of her time decorating lived spaces. I have been quite intrigued by the ways she transformed everyday places into works of art, giving so much energy not only in decorating them, but also in making them themes for her paintings ${ }^{3}$ and in sketching detailed topographies of them in her letters to her friends. Indeed Carrington was a voluminous correspondent and wrote beautiful letters both in content and in form as she was often intermingling writing with 'delightful illustrations.' (Rothenstein 1980, 10) Virginia Woolf, who was one of her correspondents, considered her letters to be 'completely unlike anything else in the habitable globe.' (cited in Hill 2000, 33) Carrington's love and passion for decorating private spaces was a constant theme of her letters throughout her life. As she was writing to Julia Strachey in March 1927:

So, I've decorated Lytton's sitting room at Gordon Square for him: very chaste. In pale green, white, and cherry red, with decorations on the mantelpiece ... Then I've painted Gerald B[renan's] new room in St. James Street, apple green 
and vermilion. And Alix has commissioned me to paint her gramophone with pictures all over it ...

This short epistolary extract beautifully brings together three of Carrington's closest friends, by way of decoration. The decision of the colours for her friends' lived spaces and beloved objects create vivid portraits of their personality, ideas and tastes: chaste colours interrupted by a cherry red for Lytton Strachey, the great love of her life; greens of the nature for Gerald Brenan who lived in a remote Spanish village and colourful pictures for her best woman friend Alix Strachey, to cover the dull surface of a technological object so important for the life of the bohemians: the gramophone. Colours became a saturating material presence in Carrington's life: it was through colours that she problematized her actuality and tried to intervene in the forms of her life and reinvent herself as one of the art objects that she was continually creating. Indeed, Carrington would paint on almost any medium she could find, including glass, tiles, pub signs, and the walls of friends' homes. As she was writing to Dorelia John on February $5^{\text {th }}, 1928$ :

... I've been drawing some designs for some rooms at Cambridge. Panels for doors, I think I shall go over there and paint them soon. It's a hideous gothic room in King's belonging to a sweet canary Don called Rylands. So I'm doing hideous gothic pictures of Roman emperors heads and Greek urns to make a nice job of it. Would you like a china plate? ... ${ }^{5}$

Carrington also made woodcuts for Leonard's and Virginia's Woolf Hogarth Press, did some leather work and designed theatre costumes, a practice she extended to her own clothes: as Jane Hill has commented 'she was always known for her odd print frocks.' (2000, 39) These persistent decorative trends in her art have invited a range of interpretations. There was the obvious need for survival, a fate shared by most artists, men and women, then and now. Carrington was dependent on a small inheritance allowance from her father: she therefore shared Bloomsbury's bohemian life-style of what Caws has succinctly described as 'semi-richness, semi-idleness.' (1990, 10) As she was writing to Brenan on December 8 ${ }^{\text {th }}$, 1926: 'I have just finished 15 little ashtrays and have sent them off to the shop. Hoping to get $£ 12$ before Christmas for them ... I always feel very pleased when I can live three days by myself completely alone without what I call 'giving way.' 6

Carrington's life-long interest in doing art with places and objects that were part of her everyday life should also be considered as an effect of her participation in the activities of the Omega project, Roger Fry's idea 'of a studio workshop where artists could earn a small regular income, decorating household objects.' (Hill, 2000, 37) Many artists of the Bloomsbury group had endorsed the Omega project including Vanessa Bell and Duncan Grant who had been invited by Fry to join him as co-directors. In the letter below written to her brother Noel in 1916, Carrington gives a humorous account of the initiation of the 'Omega Club' as she calls it and the Bloomsbury circle:

Roger Fry has started a club in Fitzroy Square called the Omega club of which I was elected a member. It has no advantages except a meeting once a week in his big rooms and the pleasure of taking two friends to the club to gaze at the comics! The first meeting was on Saturday evening. But such controversies ensued, one Clive 
Bell by name making many complications by asking idiotic questions and losing his temper on being snubbed. But it was fairly interesting as people like Maynard Keynes of the Treasury give one the Government gossip and it's pleasant seeing people again sometimes. ${ }^{7}$

The Omega project went on to do much more than meetings and Carrington got seriously involved with it. She particularly liked the central ideas of the Omega project that Fry had taken from the medieval Italian workshop system: communal art and the anonymity of the artist. For Carrington art was about creation, not celebrity. As she was writing in a letter to her painter friend Gertler: 'When you said that the artist's name didn't matter in a picture and you did not want to be a big artist yourself, only a creator, I felt I loved you more than I ever have before.' 8

Carrington's insistence on not signing her works seemed to fit well with Fry's communal ideas about art as intrinsic part of everyday life. But apart from 'erasing the painter', Carrington also loved to hide her pictures from the world: although she kept painting throughout her life, she very rarely exhibited. 'How can we get to know you if we don't see your paintings' Vanessa Bell had asked her. (Caws 1990, 18) However, Carrington was persistently resisting the Bloomsbury pressure upon her. As she was writing to Brenan in October 1920:

Lytton [Strachey] is insisting this month, on penalty of a great breach of affection that I must send a picture to the London Group show, so I suppose I shall have to. But the mere thought of seeing my half hatched efforts displayed in public almost makes me sick and suicidal. But I shall not see them even if they are accepted. For I shall never go. ${ }^{9}$

Given Carrington's life-long practice of painting but not exhibiting, it is thus no wonder that her work remained unnoticed until the end of the $1960 \mathrm{~s}^{10}{ }^{10} \mathrm{In}$ this paper I will excavate some layers of Carrington's erasure from the discourses of art histories, focusing in particular on the link between privacy and women's creativity within the gendered spaces of modernity. What I will argue is that Carrington's epistolary drawings and artistic practices are recreating and reclaiming space for the female self: they are artistic interventions in the aesthetics and ethics of the self.

My analysis follows strands of epistolary analytics in auto/biographical research: Liz Stanley's (2004) work has been influential here; I have drawn on her approach to epistolarity and particularly the proposition that narrative sense emerges as an effect of the exploration and indeed juxtaposition of wider collections of letters and bodies of correspondences, what she has theorised as 'the epistolarium.' Indeed my analysis is situated in the context of three large bodies of correspondence: Carrington's letters to Mark Gertler, Lytton Strachey and Gerald Brenan. I first read these letters in an edited collection by David Garnett (1975); the inevitably fragmented nature of this volume eventually brought me to the archives of the British Library and the Harry Ransom Centre of the University of Texas at Austin. ${ }^{11}$ Clearly my work in the archives imposed its own order of inclusions and exclusions as all archival research inevitably does. In this light my research created its own archive of published and unpublished letters ${ }^{12}$ as well as other auto/biographical sources about Carrington's work including a biography (Gerzina-Holebrook 1989) and two artists' monographs. (Carrington 1980, Hill 2000) 
Two interrelated themes emerged as crucial in this archive: the visuality of Carrington's letters and spatial entanglements in the constitution of the female self in art. Carrington's beautiful epistolary drawings eventually became a selection strategy as well as a theme in my analysis: the importance of artistic practices in the spatial constitution of the self; it is unravelling these themes that I will now turn. ${ }^{13}$

\section{A Life In/For Art}

Reluctant as she was to exhibit, Carrington has written at length about her frustration and disillusionment about not being able to seriously engage herself with her artwork and 'realize' her paintings as Cézanne, who she deeply admired, would say. ${ }^{14}$ Her letters and diaries often express her wish to work hard, focus on her art and stop wasting her time. This is what she was writing to Brenan on December $20^{\text {th }}, 1922$ :

After dinner we rushed off to a lecture by Roger Fry. He is giving a whole series of lectures. Tracing the development of design, and 'significant form' in painting. He has amazing slides, Giotto, and the Sienese school. ... Roger's lectures (on the Italian pictures) have inspired me to start some big compositions. Suddenly reviewing my last year's work it seems disgracefully amateurish and 'little'. So I shall now start this Xmas after they have all gone a composition of an interior scene in this kitchen. Only I shall paint it very big. I do not want to tackle anything too difficult, or I know I shall then despair and give up the composition before it is finished. ${ }^{15}$

Carrington's letter shows her deep interest in the history of art, which she considered critical in how her own style and techniques could be developed. In the passage above she promises her friend to 'start this Xmas after they have all gone'. Who were the 'they' she wanted to get rid of and what was it that stopped her from devoting herself to her art? Carrington lived of course in an era when gendered discourses and practices were dominant in the artworld. However how powerful were these discourses amongst the bohemians or her famous Bloomsbury friends? Carrington had followed a different path in life away from conventions and middle class ideologies; but as it has been widely discussed the Bloomsbury intellectuals were always positioned in a liminal position between traditions, always relying on 'imaginative recombinations of available conventions.' (Reed 1996, 149) 'Difference' has thus to be considered relationally here, a diversion rather than a complete rift with dominant structures and ideologies. It is these diverting paths in Carrington's life that I now want to retrace.

Carrington was born in Hereford in 1893 and came from a middle class family; her talent for art was manifested early in her life and in 1910 she got a scholarship to study art at the well-known Slade School of Art in London. Founded in 1871 as part of University College London, the Slade was an institution departing from the conventions of the Royal Academy of Art and modelled upon the teaching methods of the French ateliers: there were no classes as such, only courses of study: drawing from the antique and life; sculpture; painting from the antique and life; composition; perspective and lectures. Women were included in all of these courses, although 'ideas of sexual difference were manifested at the Slade in the segregation of male and female students into separate rooms for the most important aspect of Slade training, life drawing.' (Foster 1999, 11) 
Notwithstanding the constraints imposed by the ideologies of sexual difference, the Slade was the first art school to allow women to work from the life-model in the UK and had therefore become popular amongst women, 'who made up approximately twothirds of the students at this time.' (Foster 1999, 10) As Hill has noted, Carrington's four years at the Slade (1910-1914) were at the heart of 'the most transitional and influential time of its history' $(2000,11)$, particularly in recognising and warning women students about the real life and invisible barriers they would face in their attempt to pursue a career as professional artists.

During the Slade period many things would change in Carrington's life and self perception. Going away from her middle-class parental home and being immersed in the bohemian circles of London would have a significant impact upon her. She dropped her first name and had her hair cut short in the kind of bob that was becoming the symbol par excellence of the New Woman. ${ }^{16}$ Her intellectual development was also striking. As her brother Noel has noted about Carrington's Slade years: 'I recall another shock I received at this time. Though a couple of years younger, I had a schoolboy's sense of mental superiority over any girl, and here she was reading books beyond my ken: Tolstoy, Tristram Shandy, Mary Woolstonecraft and Romain Rolland.' (Carrington 1980, 21)

Moreover Carrington's years at the Slade were successful in terms of artistic creation and recognition: she soon became noted and won a series of prizes and a scholarship, which allowed her to continue her studies at the Slade for the next two years (1912-1914). It was also during these years that she got involved in the first amorous relationship with artist Mark Gertler, who introduced her to the Bloomsbury group and to Lytton Strachey, who she loved passionately to the point of committing suicide shortly after his premature death in 1932. A member of 'the Old Bloomsbury group', Cambridge educated but not yet having written the books that made him famous ${ }^{17}$, Strachey would have a long-lasting impact upon Carrington: they stayed together in friendship and in love in different spatial, emotional and personal arrangements till the end of their lives. Strachey was a great friend, an unattainable lover - given his outspoken homosexuality within a heteronormative society - but also a mentor throughout Carrington's life. As she was writing to Brenan: 'Sometimes with Lytton I have amazing conversations. I mean not to do with this world, but about attitudes and states of mind, and the purpose of living. That is what I care for most in him.'18

After graduating from the Slade, Carrington spent three difficult years (19141917) trying to find her way as an artist, on and off with Gertler and in and out of her parental home. The lack of money has particularly been deplored in her letters. As she was writing to her brother Noel in 1916: 'I say dearie can you lend me a few sheckles to live on as I had to pay some tiresome bills before I left London [...] I've just got a commission for $£ 2 / 10$ out of John Folhergill to do a woodcut otherwise times are bad. ${ }^{\prime 19}$ Borrowing money from friends and family was thus amongst Carrington's tactics of survival during these years. But as the letter above shows she was not totally dependent on borrowing; already since her Slade years Carrington had tried hard to support herself: she would take commissions, work as a private art tutor and in 1914 she had even managed to sell her first drawing for $£ 58$ s through participating in a NEAC exhibition. Making woodcuts for books was a constant source of income for her, as the passage above shows. Slowly but steadily, Carrington was thus in the process of making a living as an artist despite the insecurities inevitably inherent in an artists' career. 
In the process of becoming independent, in 1917 Carrington moved with Strachey in Tidmarsh Mill, a country house in Pangbourne, Berkshire, where they lived together till 1924, when they moved to Ham Spray House near Hungerford in Wiltshire where they both died in 1932. Her move to Tidmarsh Mill signalled the definitive end of her amorous liaison with Gertler, although they went on exchanging letters for much longer. The small inheritance her father left her after his death would allow her to survive and go on pursuing her art albeit with difficulties. In 1918 she met Ralph Partridge through her brother Noel. They became friends and lovers and Partridge moved in Tidmarsh Mill sharing his life with Strachey and Carrington who he eventually married in 1921. This is an [idealized] epistolary depiction of her life with Strachey and Partridge at Tidmarsh Mill in a letter to Brennan on February 1 $^{\text {st }}$, 1920: 'I am reading such a good book by Hudson called the notebook of a naturalist [...] Whilst I painted RP this morning Lytton read Edward II by Marlow [...] Do you know how much I love this life here? It combines all I want I think.' ${ }^{20}$

Carrington officially remained Partridge's wife till the end of her life but theirs was a complicated relationship with other lovers for both in between and a variety of emotional and living arrangements, something that was not unusual in the bohemian circles and the Bloomsbury group attitudes and life styles. Carrington's relationship with Gerald Brenan, a writer and critic living mostly in Spain was an important one and her correspondence with him went on till the end of her life.

Carrington had equally passionate relationships with women whose portraits she painted and to whom she wrote beautiful and emotionally charged letters. In 1923 she met and fell in love with Henrietta Bingham, and in 1925 she fell for Julia Strachey, Lytton's niece, a novelist and an art student at the Slade. Carrington's amorous attraction and passion for women however, was again to dissolve in the heteronormative matrix of her times and geographies: even within the cracks of the bohemian circles, women's homosexual relationships were difficult to be recognized and registered. As she was writing to Brenan on July $21^{\text {st }}$, 1925, she was always grappling with 'this struggle with two insides, which makes one disjointed, unreliable and secretive.'21 Women remained a catalytic presence in her life however: she often referred to 'extraordinary' women within and beyond the Bloomsbury group in her letters. As she was writing to Brenan on January $12^{\text {th }}, 1923$ :

... Virginia is as much of a genius as anyone I think alive in England and one ought not to treat sensitive people like her as if they were ordinary people ... I think Murry is a little too much of a businessman. He is already bringing out a book of Katherine Mansfield's letters edited and very much abridged I expect by himself. Katherine was a very remarkable woman ... Lytton told me the story of George Sands ... She lived in her novels and could not bear to be with a man a week unless he was passionately in love with her ...22

By creating a genealogical line of extraordinary women, Carrington was also reflecting on the gender politics of the bohemians and also displayed a clear consciousness of how letters in general [and perhaps her own letters in the future] entered discourses and practices that were inevitably outside the control of their authors or even correspondents. This realization surely must have had real effects on what she wrote and how she wrote; ${ }^{23}$ it also has an effect in her many letters that we will never read, since she deliberately 
destroyed many of them. As revealed in a letter to Brenan written on January $31^{\text {st }}, 1923$ : 'You do not know the attic ... I sit ... writing at an old Victorian desk ... I also burnt another thousand letters yesterday.'24

What surely remains important is that women either as friends or as lovers were Carrington's confidantes, throughout her life. As she was writing to Brenan again in February 1920: 'Your idea about making an announcement in the Times about my secret feelings and complexes is a good one! ... But I tell everything to Alix [Strachey] who is my confident. Yes she knows absolutely everything I think. ${ }^{\prime 25}$ In a letter to Brenan written a year after, on August 7th 1921 , she was commenting about Alix: 'It's delightful to have Alix with me again. I love her very much. She is so unlike other women, so impersonal, more like a man.'26

What I have tried to show so far is that Carrington's emergence as an artist was a long process that started early in her life, was supported by her family and was founded on a sound academically based art education. Her involvement with the intellectual and artistic circles of Hampstead and Bloomsbury further created conditions of possibility to sustain and support her career as an artist. Although she did get marry, she never had children and followed the unconventional life style of the bohemians. Painting was a lifelong passion for her, a force of life that moved her beyond spatial, cultural and emotional boundaries. As she had written in a letter to Strachey: 'I am never so happy as when I can paint.' ${ }^{27}$ Why was it then that she had so much difficulty in devoting herself to her art?

Having worked at length with Carrington's rich and artistic letters, what I suggest is that her difficulty should be mapped in a relatively unexplored area: the relationship between the public, the private and the right to privacy. My argument is that Carrington could not 'realize' her art not because she did not have access to the public world, but because on the contrary she was over exposed to the bohemian circles of London and could not keep them from interfering with the calmness and solitude that an artist needs so as to be absent-minded and creative. It was the right to solitude that Carrington was lacking, as passionately expressed in the following letter to Brenan written from Ham Spray on October 20th, 1924:

If I come up to London it will mean the whole of this good effort to keep working disturbed. I have been making elaborate drawings all this week for this picture. Now there is nothing to be done but to push on and get the picture painted. Ideas keep on crowding into one's head as one works. One sees everything new when one wakes up and makes alterations ... If I abandon it for two days I shall lose so much ... Oh Gerald please, don't make it hard for me to work. The whole of everything regarding myself I feel hinged on my painting. ${ }^{28}$

What Carrington was trying to communicate in the above letter is that the excitement of the bohemian exuberance in London was a hurdle in how her work was developing. She knew that not only through despairing with the slow progress of her work, but also through comparing herself with her companion's creativity. When Carrington and Strachey went to live in Tidmarsh Mill, this was a strategic move funded by Strachey's brother Oliver and his Bloomsbury friends, ${ }^{29}$ who had realized that Strachey needed a quiet private space to finish his manuscript Eminent Victorians that actually came out a year after their move to Tidmarsh Mill, in 1918. Strachey had found the space and solitude he needed to write, but what about his female companion? It was actually Carrington's hard 
work in transforming Tidmarsh Mill into a quiet place where Strachey could relax, think and write that had created conditions of possibility for his celebrated books to be written. As Strachey was writing to Virginia Woolf on December 21st, 1917: 'My female companion keeps herself warm by unpacking, painting, pruning the creepers, knocking in nails, etc.'30

Carrington was less successful however in creating spaces for herself. What constantly emerges from her letters is her disappointment with her art and an on-going desire to find more time and space to paint. On July 1st, 1929 she was writing to Julia Strachey: 'An awful depression overtook me yesterday after looking at all these lovely pictures. My life has been frittered away without producing anything worth looking at. You must at least learn by my sad example and finish your novel.' ${ }^{1}$ In thus trying to look closer into the nuances of Carrington's existential difficulty to realize herself as an artist, I will now explore the microphysics of her spatial practices, drawing on Foucault's analytics of power.

\section{The dark sphere of privacy}

Theorising the social nature of spatiality and its interdependent relation with power and subjectivity, Foucault has pointed out that 'a whole history remains to be written of spaceswhich would at the same time be the history of powers' (both these terms in the plural).' (1980, 149) The troubling genealogy of power relations around women and 'the private' is I suggest one of those histories that have yet to be written. In this context, a line of thought I would like to follow in this paper is what borrowing from a Foucauldian glossary I have called the private hypothesis - the long held argument that women have been constituted as figures of the private and have been concealed within it. What I argue has been conflated in the private hypothesis is the realm of domesticity with the private sphere.

In highlighting this problematic conflation between domesticity and 'the private', a critical question arises: how is the domestic to be perceived within the spatial context of a woman artist's life? Domesticity has indeed been a hot area of feminist theorization and a lot of feminist ink has been split on arguments linking women's liberation with the rejection of domestic ties as well as post-feminist counter arguments challenging constructed dichotomies between the domestic, the private and the public. ${ }^{32}$ Domesticity has also been challenged in art histories revolving around the Bloomsbury interiors in particular. In writing about the Bloomsbury Rooms, Christopher Reed (1996, 2004) has shown how a different ideal of domesticity was amongst the concerns of the Bloomsbury group as part of the aesthetics and politics of everyday life. In looking into architectural and decorative arrangements of English interiors created by members of Bloomsbury and particularly Vanessa Bell, Duncan Grant and Roger Fry, Reed has argued that while criticizing mainstream domestic culture, Bloomsbury's alternative domesticity was an important subculture within modernism. Interestingly enough Carrington's houses have not been included in Reed's analyses, understandably so since her decorative style was not Bloomsburyean despite the obvious influence of the Omega Workshops. As Hill has noted Charleston, Bell and Duncan's famous Sussex house, had clearly influenced Carrington's decorative trends, but she did find it overloaded and 'rather shambolic.' $(2000,56)$ 
Although Carrington's decorative trends were diverting from the Bloomsbury artists what she surely shared with them was the idea of a home sustaining and supporting the creation of "good things in life". These ideals have mostly been crystallized in Clive Bell's, famous essay, Civilization: 'a taste for truth and beauty, a dislike of vulgarity and brutality, freedom from superstition and prudery, a fearless acceptance of the good things in life.' $(1928,210)$ When planning the cottage of her dreams with Strachey, Carrington must have surely shared his ideas about the necessity of 'a room of one's own' as expressed in one of his letters to Duncan Grant written in 1909: 'Good God, to have a room of one's own with a real fire and books and tea and company, and no dinner bells and distractions and a little time for doing something! It's a wonderful vision and surely worth some risks. ${ }^{\prime 3}$ It seems that Carrington was willing to enter such risks, without having realized at the time that Strachey's 'room of one's own' was a deeply gendered idea in need of a woman carer to be materialized. Carrington took up this role but she would soon find out the gendered limitations and constraints of the Bloomsburyean 'altrernative' domesticity. In the following letter to Gertler where Carrington recounts her first meeting with Strachey in Leonard and Virginia Woolf's house at Asheham in December 1915, the gendered limitations of the 'alternative ideal of domesticity' are clearly demarcated:

I have just come back from spending three days on the Lewes downs with the Clive Bells, Duncan [Grant], Mrs Hutchinson and Lytton Strachey. God knows why they asked me!!! It was much happier than I expected. The house was right in the middle of huge wild downs, four miles from Lewes and surrounded by a high hill on both sides with trees [drawing here] We lived in the kitchen for meals, as there weren't any servants, so I helped Vanessa [Bell] cook. $^{34}$

Domesticity is thus a contested area, while 'the private' has a troubling history of its own, which is gendered and classed, but not necessarily linked to domesticity. As influential theorists have shown, the private self has always been a sine-qua-non condition for the very existence and sustainability of the public/political self. According to Foucault (1988), knowledge and care of the self in classical antiquity and the hellenistic era were everyday private activities aiming at the cultivation of the private self and [his] preparation to enter the political arena. Retreat into oneself historically became a condition of possibility for the actual 'care of the self'. Hannah Arendt has further discussed how privacy has always been the dark side of the public realm and has emerged as a condition of being human: 'Privacy was like the other, the dark and hidden side of the public realm, and while to be political meant to attain the highest possibility of human existence, to have no private place of one's own (like a slave) meant to be no longer human.' (1998, 6) Privacy for the early modern age, Arendt has further argued 'was actually the guaranty of isolation, without which no work can be produced.' (1998, 161)

Retreat and isolation within the private sphere have therefore been theorized as essential conditions both for the constitution of the political self and for creative forces to emerge. But as I have shown in my previous work (Tamboukou 2003) the tradition of 'the care of the self' has been marked by gendered, classed and racialized ideologies and discourses. My proposition is therefore that women's spatiality has been the effect of particular normalizing technologies of power, which have historically left them concealed within 'the private sphere' of domesticity but deprived them of the right to solitude within 'the private'. This condition did not necessarily change when (some) women entered 'the 
public world' at the turn of the twentieth century. The right to privacy has remained a grey area in the histories of how the female self has been spatially constituted as a subject. In this context for Carrington and for many of her contemporaries, it was not so much their presence in the public sphere that was unattainable. As beautifully put in a letter to Gertler written from the 'Arc', a room Carrington had taken at 3 Gower street, the year before she moved to Tidmarsh: 'It's wonderful being alone up here so high myself. I wish sometimes I could bolt the door and live in here for days and days and not get disturbed by all this outside world of people.'35

Carrington's desire to live alone and undisturbed by crowds is striking in this passage. Feminist geographers have discussed discursive expressions of women's fear of crowds and have made psychosocial connections between conscious and unconscious feelings of fear charting their socio-historical and material conditions. Joyce Davidson (2003) has particularly considered phobic spaces and gendered relations. Seen in this light, one could argue that Carrington's letters emit signs of agoraphobia, however such letters always co-exist with her desire to be out and about, meeting people, going to parties and even riding motorbikes: "My greatest pleasure is a motorbike which I am going to learn and then all England is within my grasp" she was writing to Lytton in June 1916. ${ }^{36}$ Within a month her motorbike dream had become a reality: 'Do you know I can ride the motorbicycle now all around Regent's Park before breakfast tearing quicker and quicker leaving gaping faces of city clerks behind on either side' she was triumphantly announcing in a follow-up letter dated June $13^{\text {th }}, 1916 .{ }^{37}$ What I want to restate here is that being part of and moving through public spaces was not so much a problem for Carrington: what has been the most difficult passage for her - as well as for other women artists in the bohemian circles - was grappling with and negotiating privacy within the spatial arrangements of everyday life. As my overall project of writing a genealogy of the female self in art has shown (Tamboukou 2010a), fin-de-siècle women artists worked hard to safeguard privacy: Gwen John for example who was also a Slade student from an older generation, left London and lived and worked in Paris on her own. Her letters beautifully express her desire to live away from people and create in solitude. In writing Rosa Bonheur's auto/biography the American artist Anna Klumpke has highlighted Bonheur's decision to move from Paris to a village near Fontainebleau, where she could work in peace. (See, Tamboukou 2010a, 74)

In this light, Carrington's long-life commitment to making the living places of her actuality into works of art thus becomes an extremely interesting theme. In her letters, which were actually part of her artwork, privacy emerges as a contested and troubled area, something to yearn and struggle for; it is this line of the struggle for privacy traced in Carrington's letters and epistolary drawings that I now want to take up in the following section of this paper.

\section{Re-imagining the private: Carrington's spatial technologies of the self}

... for the last two days I have toiled unceasingly creating ORDER. Really it is magnificent. An upstairs attic adjoining my bedroom studio practically I have transformed in a workshop of the most marvellous system. The shelves are divided into stalls in each stall tubes of different colours lie neatly arranged so at a glance I can find my colours and they can never get confused. This is really an invention, 
for paint boxes are never large enough to contain all one's paints. I now simply go to my attic put the paints I require on my palate, do all my canvas stretching \& messy work in this room, leave it and paint in a clean tip room down-below. Why I never thought of it before ... I have a lock for the door, so I can safely leave my canvasses exposed in this retreat. I discovered a high calamity whilst cleaning this attic, which before was all confusion as I simply used it as a safe depository for my drawings and canvasses. The Rats had eaten their way through the wall and had nibbled off the drawings that projected from my portfolio. The result was that nearly all the drawings were decapitated. My fine buzzard, which was full size (a pen and ink drawings I always intended to give you), which I once made from a stuffed bird in Cornwall, had lost its head! The floor was a mass of fragments of paper. Hardly a drawing escaped their ravages. I think it's terribly depressing looking at one's past work. I intend to paint out every single canvas and burn all the drawings tomorrow. ${ }^{38}$

The above extract from a letter written to Brenan on October $12^{\text {th }}$, 1921, depicts Carrington's efforts to create space for her art through a rearrangement of domestic places: the bedroom and the attic. ORDER in the arrangement of colours would make up for the difficulty of lacking a 'studio of her own.' Since Carrington felt disoriented as an artist, retreating in the attic and creating ORDER there would become a spatial condition of possibility for her subjectivity as an artist to emerge in the derelict space of the attic. Brian Massumi (1993) has particularly referred to the power of 'derelict spaces' to shelter subjectivities in crisis. In Carrington's epistolary discourse then, the attic becomes a zone of indeterminacy that an artist-in-becoming may make her own, since who was going to bother about it? Carrington's particular reference to the lock for the door and the need to safeguard privacy and her work within the 'private' domestic realm is also an exciting line of her letter. Moreover, the disaster that the rats have left behind could also be read as a spatial metaphor of Carrington's anxiety about losing her orientation as an artist. Indeed, while loving her houses and working for them, she had ultimately found herself without a studio of her own, a space where she could work without interruption.

Carrington's lack of a studio of her own, rehearses Virginia Woolf's influential lectures at Girton and Newnham in 1928 about the importance of personal space in women's creativity. It is here interesting to note however, that in a letter to Strachey on November $6^{\text {th }} 1929$, a year after Woolf's lectures, Carrington had actually written that she did not agree with Woolf's idea of 'a room of one's own' as a necessary precondition for women's creativity: 'Virginia is fascinating. But I still don't agree that poverty and a room of one's own, is the explanation why women don't write poetry. If the Brontës could write in their rectory, with cooking and housework, why not other clergyman's daughters?'39 Maybe Carrington was not persuaded because her life was actually a counter-example of Woolf's influential suggestion: she had this 'room of her own' - or thought she did - as well as some sort of financial independence and yet her creativity had not advanced at least in her own expectations. As the epistolary passage above frightfully reveals, after spending years working tirelessly to transform Tidmarsh Mill House in a quiet place where Strachey could retreat and write the books that made him famous, Carrington was to find her work destroyed by the rats in the attic, the only place in the house that she had managed to keep as a storage space for her drawings and art 
material. But it was not just space that Carrington was lacking, but also time and solitude. As she was writing to Brenan on May 20th 1919 , the many visitors coming over to Tidmarsh from London would leave no time or space for her passion for painting:

I've become rather ambitious about my paintings lately. I want frightfully badly to so arrange my life that I can paint a great deal more and also more powerfully. At present I am so uncertain of myself. And have so little confidence in consequence ... Next week Clive Bell and his cohort come here for 4 days. I always grudge visitors. Rather as they involve me leaving my painting and doing fatigue duties which I detest. $^{40}$

In this light and despite the many houses that Carrington both inhabited and painted, what I suggest emerges in the charting of her spatiality is a spaceless female subject. However is it ever possible for human beings to be declared spaceless? After all, the materiality of their body cannot be annihilated by the declaration of some hypothesis. In suggesting that Carrington was hovering over a spatial void, I refer to the existential spatiality of the female subject. In this light, what has been defined as private - take Carrington's homes for example - become spaces wherein women lose themselves, 'nonplaces' for women. In my proposition of considering home as a 'non-place' in the constitution of female subjectivity, I am drawing here on Mark Augés concept of the 'non-place' as 'a space which cannot be defined as relational, historical or concerned with identity.' (1995, 77-78) Three counter-arguments could be raised here of course: first the fact that 'women's locations', within the private sphere of the home have always been relational-populated by parents, husbands, children, or even lovers, as in Carrington's case; second, women's seclusion within these domestic locations has been a deeply historical phenomenon, and third, 'women's locations within the private have created conditions of possibility for the construction of their identities as wives, mothers and dutiful daughters. In this light they are places of and for women. I could agree that they are indeed places where the figure of the Woman is both constituted and represented in gendered discourses and practices. My suggestion however does not refer to the patriarchal figure of the Woman. What I argue is that home is a 'non-place' for the subject of feminism, which according to de Lauretis' emerges 'from current writings and debates within feminism [...] at the same time inside and outside the ideology of gender, and conscious of being so.' $(1987,10)$ As de Lauretis has discussed, there has always been a tension between how women are represented and constructed in discourse and how they actually live their lives, as 'historical beings' and 'subjects of "real" relations'. (10) It is this critical tension that my suggestion of the 'non-place' is addressing here. Carrington's spacelessness I argue is a sign of the problem that home has historically functioned as a 'non-place' for the unfolding of women's creativity. It has actually been a location absorbing the spatiality of their existence, continuously reterritorializing them in 'striated spaces', interrupting their 'becoming other'. ${ }^{41}$

Therefore it is not that within the patriarchal spaces of modernity women have not been offered and claimed physical locations or places to inhabit; they have indeed been assigned to and often participated in placing themselves in various locations within designated realms of 'the private' and 'the public'. However, a number of places that have been discursively defined as 'women's locations', be these their bedrooms, kitchens or even classrooms have been historically structured along disciplinary lines of continuous 
and invisible surveillance, practices that I argue annihilate any sense of privacy within 'the private.' A rich body of feminist research has indeed demonstrated that spatial alienation is a constitutive axis in the construction of the female self, while women's sense of estrangement from the everyday spaces of their lives has been shown to be related to fear, the fear that they are always watched and evaluated. ${ }^{42}$ As Gillian Rose has argued, this threat of being the object of the other's gaze is of critical importance in the objectification of the female subject. (1993, 146) It is in this light I suggest that the history of traditional 'women's locations' is actually the history of women's oppression, a history that has to be overwritten and/or juxtaposed by a myriad of counter-histories 'of spaces and powers' according to Foucault's aforementioned suggestion. At the same time, however, it is from this void of woman's non-representation, the non-place of the actuality of her life, a spatial elsewhere as de Lauretis has put it, that counter-narratives of space emerge from:

... that 'elsewhere' is not some mythic distant past or some utopian future history; it is the elsewhere of discourse here and now, the blinds spots or the space-off, of its representation. I think of it as the space in the margins of hegemonic discourses, social spaces carved in the interstices of institutions and in the chinks and cracks of the power-knowledge apparati. $(1987,25)$

In this context, Carrington throughout her life seems to have been caught in the paradox of setting up and decorating houses that would shelter and indeed forge the creative forces of her male companions at the same time of disorienting her creative forces, dispersing her own existence. But it was also within the interstices and ruptures of these segmented spaces that she strove for a studio-space of her own. Her letters and beautiful epistolary topographies, her love and passion for decorating lived spaces and her paintings carry traces of lines of flight and deterritorializations from striated spaces and open up smooth spaces in the cartography of her spatiality as I will further show.

\section{Ethics, Aesthetics and Politics}

As already discussed, what is significantly interesting about Carrington is that although she very rarely exhibited, her art has been vividly depicted in the private realm of her lived spaces. Hill has suggested that Carrington's houses 'were like pictures inside which she lived.' (2000, 9) These houses should be also seen as works of art that 'established the legacy of her taste', Hill has further commented. (48) It is no wonder that Carrington loved these everyday spaces passionately, decorated them, turned them into beautiful paintings, drew them in her letters and wrote about them. In an entry in her diary shortly before she committed suicide she noted: 'Looked through all my old pictures to find some of Lytton to give James. Tidmarsh all came back. How much I love places.' ${ }^{43}$ On November $23^{\text {rd }}$, 1923 as she was about to leave Tidmarsh to move to Ham Spray, she was writing to Gerald Brenan: 'I am in love with a house.' 44

Carrington's letters further depict that the practice of making her space a work of art, would become almost synonymous to making her life a work of art. Intervening in the aesthetics of her surrounding spaces would be linked to a politics of a different life. In making this suggestion I draw again on Foucault's idea about the political necessity of 
making one's life a work of art: 'From the idea that the self is not given to us, I think that there is only one practical consequence: we have to create ourselves as a work of art'. (1986, 350) Foucault actually links this suggestion with an observation that if we are surrounded by art objects in our everyday life, why can't we render our life itself a work of art: 'why should the lamp or the house be an art object, but not our life? (351) In fleshing out this line of thought, Jon Simons $(1995,76)$ has discerned three central themes in the Foucauldian aesthetics and its relation to politics: a) demands of style, b) artistic practice as a source of empowerment and c) working with present conditions and limits.

In Simon's analysis, the demands of style is the never-ending struggle for transgressing the limits that constrain but at the same time define the very existence of human beings. Artistic practices create possibilities for transgression and thus become a source of empowerment and sites for the emergence of new subjectivities: 'one creates new modalities of subjectivity in the same way that an artist creates new forms from the palette' (Guattari 1995, 7). In the process of artistic creation Carrington remakes the spaces of her actuality and in the process of seeking new forms for the spaces and objects that surround her, she also invents new forms for the self, re-imagining herself as a woman and artist embedded in space-time-matter conditions of artistic creation.

The artist's hand and mind are thus crucial for the creation of new forms, in life and in art. Since an artist knows that 'creation of form is not a matter of spontaneity, impulsiveness, licentious abandonment and irresponsible energy' (Simons 1995, 77) she can more easily transfer the artistic experience and practice in creating new forms for her life, 'new modalities of subjectivity'. Moreover artists know that artistic practices work better when there is a need, an urgency, a question to be answered, a problem to be resolved. Foucault has drawn on this agonistic character of the artistic practice in its transposition as a practice on the self. ${ }^{45}$

What is crucial in considering women artists' aesthetic work is that the artistic practice and the self technology often converge: 'I am always happy when I paint' Carrington had written to Strachey as already noted above. ${ }^{46}$ In this sense Carrington painted and decorated her everyday spaces and this artistic practice was actually becoming what Foucault (1988) has theorised as a technology, a technique of the relation to the self, an invention of a mode of existence. ${ }^{47}$ Foldings and unfoldings are crucial in these processes of self-formation. Elspeth Probyn has particularly pointed to the crucial concept of the fold in both Foucault and Deleuze's analyses, foregrounding the very constitution of subjectivity as an incessant process of folding and unfolding: "The act of pleating or folding ("la pliure") is thus the doubling-up, the refolding, the bending-ontoitself of the line of the outside in order to constitute the inside/outside - the modes of the self." (1993, 129)

The different spaces and places that Carrington lived in and recreated thus fold into her body activating a series of movements, practices, thoughts and affects. As she remakes her lived spaces, she folds out into the world constituting herself as a subject. Spaces and bodies are thus interrelated in a continuous process of folding, refolding and unfolding. And yet this creation, these becomings are always pragmatic: they have to be actualized within present conditions and limits: 'depending on the balance between enabling limits and constraining limitations, between lightness and heaviness, we have more or less capacity to create ourselves as works of art', Simons has noted. $(1995,77)$

In this light, Carringtons letters, her epistolary topographies, the decorative trends in her art and her beautiful paintings of lived spaces created conditions of possibility for 
transgression and change. Escaping the suffocated spaces of her middle-class parental home was both a problem of freedom and a matter of taste. On September 23 ${ }^{\text {rd }} 1926$, she was writing to Strachey: 'Darling Lytton, here I am plunged in the middle of Benares brass life, and Japanese screens ... I can't write you a letter, I am too depressed by the hideousness of this house.' 48 While still living in this 'hideous' house she had actually attempted to intervene in its aesthetics and therefore its domestic politics. As she was writing to her friend Christine Kühlental: 'I painted the cupboard a lovely blue and red and green and the board round the bottom of the wall green and the window sill and my bed bright blue and distempered all the walls a creamy white.' 49 The artistic practices of decorating her parental home can thus be considered as 'the artist's cut', an agential intervention in the material entanglements of her spatiality and consequently in the forms of the self.

As already discussed above, Carrington would soon escape the parental home living in a series of rooms in central London of which she wrote fondly in her letters. The following letter to her brother Noel written in 1917 from 60 Frith Street in Soho, draws a vivid topography mingling words and drawings:

We moved here a week ago and a very comfortable little home it is. Only rather noisy. But an excellent housekeeper looks after us and cooks. I have a bedsitting room and a bathroom adjoining it. Alix has a big sitting room and a kitchen and small bedroom on her floor. But I can use the upstairs rooms also. The walls are rather decently panelled only a vile green paint over everything ... it's so near the restaurants and not having to bother about tramping miles to find a snack to eat. ${ }^{50}$

Carrington wrote many letters about her room/studios in central London, giving details of the furniture and their ambience. This is how she was writing to Gertler about a small studio she had taken in 16 ${ }^{\text {th }}$ Yeoman's Row, Brompton in 1916: 'My little bedroom is so beautiful to sit in, in the evenings lighted by just one candle with its low beamed ceiling and dark panelled walls, my only sorrow is that I have not you and Brett to share it all.'51 The view from the window would also become a theme to write about: 'I love my bedroom window. It is pleasant to continually have a beautiful landscape to look out on and always different. It is hard to remember that last week it was white with snow, as today it is all green and raining. Big carts of hay go past on the road.'52

Carrington's letters are indeed filled with exquisite drawing and snapshots of interior and exterior spaces that are deployed in a continuous interaction as they compose new images about the art of living and the art of being. A letter to Brennan written on June $6^{\text {th }}, 1923$ to thank him for a beautiful bedspread thus becomes an opportunity to reflect about the limitations of the spatial arrangements upon her life and creativity: it will lie as a covering to the little bed in the attic [which] is now definitely my studio, I no longer use my bedroom. I am there removed from the world and I hope this elevated change will have a great effect on my work...'53 In a later letter written from Paris on January 23 $3^{\text {rd }}, 1924$ she fervently anticipates their move from Tidmarsh to Ham Spray where: 'I shall have at last a studio to paint in, big enough to do large pictures. You can't think what that means to me after so many years with no proper room. ${ }^{54}$ A studio to come was thus a spatial metaphor for the artist to become, a space opening up future possibilities yet to be realized. 
Like many of her contemporaries, Carrington fashioned her life along aesthetic sensibilities that she was constantly immersed in as an artist, but also as a New Woman. As already noted she was deeply influenced by the artistic tendencies of the Omega workshops in developing a life-long interest in doing art with places and objects that were part of her everyday life. What I have found particularly intriguing in working with Carrington's letters is the inscription of a constant interplay of relations of power and forces of desire within what I would like to call a plane of spatial practices of the private. Feminist research in the history of art has shown that women artists have had a long struggle for a studio of their own ${ }^{55}$. Indeed, women artists' private places, their homes, rooms or studios, have become significant albeit not as the 'natural' milieu where they belong - the domesticated private sphere-but as strategic places, places set up to temporarily shelter the female subject in her nomadic passages. Indeed Carrington emerges as a nomadic figure (Braidotti 1994), wandering in between subject positions, never being able to be pinned down or identified with any of them. Elaborated as they were Carrington's rooms and later homes were after all places to be remade and then be left behind, places to leave, not to settle down. ${ }^{56}$

While however as already mentioned, a wide range of studies have analysed and sufficiently documented women artists' interventions in the public spaces of modernity, little attention has been paid to women's tactical uses of the private sphere in terms of how they have negotiated their right to privacy within the private. It is this cluster of relations of spaces and relations of powers as they converge in the grey area of privacy that this paper has particularly sought to address, revisiting the so-called private hypothesis by way of Carrington's letters and epistolary drawings. What these 'documents of life' (Plummer 2001) have unveiled is a multiplicity of discourses and practices revolving around a woman artist's intense preoccupation with the micropractices of the private.

Carrington and many of her contemporaries have used, painted and written about private places and they have constantly transformed them into a variety of spatial levels: as places where they could hide and disengage themselves from the turbulence of life; as artistic territories wherein they could be inspired and create; as homes where they would welcome their friends and sustain social relationships; as shelters of love beyond heteronormativity and even as quarters where they would exhibit and negotiate commissions. Negotiating the private and keeping alive the passion for painting would thus become a crucial practice of self-formation, a spatial technology of the female self.

\section{Archival sources}

Harry Ransom Humanities Research Centre (HRC), the University of Texas at Austin: Dora Carrington (DC) Collection, Gerald Brenan (GB) Collection

British Library, Manuscripts (BL): Dora Carrington correspondence with Lytton Strachey [Add. 62888-62897], Dora Carrington Diary: DC Partridge, Her Book [Add. 65159]

References

Arendt, Hannah. (1958) 1998. The Human Condition. Chicago: University of Chicago Press. 
Augé, Mark. 1995. Non-places, Introduction to an Anthropology of Supermodernity. London and New York: Verso.

Bell, Clive. 1928. Civilization: An Essay. New York: Harcourt, Brace and Co.

Carrington, Noel. 1980. Carrington: Paintings, Drawings and Decorations. London: Thames and Hudson.

Braidotti, Rosi. 1994. Nomadic Subjects. New York: Columbia University Press.

Caws, Mary Ann. 1990. Women of Bloomsbury: Virginia, Vanessa and Carrington. London: Routledge.

Davidson, Joyce. 2003. Phobic Geographies: The Phenomenology and Spatiality of Identity. Aldershot: Ashgate.

De Lauretis, Teresa. 1987. Technologies of Gender: essays on theory, film and fiction. Basingstoke: Macmillan Press.

Deleuze, Gilles and Guattari, Felix (1980) 1988. A Thousand Plateaus: Capitalism and Schizophrenia. Translated from the French by Brian Massumi. London: The Athlone Press.

Doran, Michael. 2001, ed. Conversations with Cézanne. Translated from the French by Julie Lawrence Cochran. Berkeley, Los Angeles, London: University of California Press.

Felski Rita. 2000. Doing Time: Feminist Theory and Postmodern Culture. New York: New York University Press.

Foster, Alicia. 1999. Gwen Fohn. London: Tate Gallery publishing.

Foucault, Michel. 1980b.'The Eye of Power', a conversation with Jean-Pierre Barou and Michelle Perrot. Translated from the French by Colin Gordon. In Colin Gordon, ed. Power/Knowledge: Selected Interviews and other writings 1972-1977, 146-165. London: Harvester Wheatsheaf.

Foucault, Michel. 1986 'On the Genealogy of Ethics: An Overview of work. In The Foucault Reader, ed. Paul Rabinow, 340-372. Harmondsworth: Peregrine.

Foucault, Michel. 1988. "Technologies of the Self". Technologies of the Self, eds. Luther, H. Martin, Huck Gutman and Patrick, H. Hutton, 16-49. London: Tavistock.

Garnett David. 1975. Carrington: Letters and Extracts from her diaries. London: Cape.

Gerzina Holbrook Gretchen. 1989. Carrington. New York and London: W.W. Norton and Company.

Giles, Judy. 2004. The Parlour and the Suburb: Domestic Identities: Class, Femininity and Modernity. Oxford: Berg.

Guattari, Felix. 1995. (1992) Chaosmosis: an ethico-aesthetic paradigm. Translated from the French by Paul Bains and Julian Pefanis. Sydney: Power publications. Hill, Jane. 2000. The Art of Dora Carrington. London: The Herbert Press.

Hollows, Joanne. 2006. 'Can I go home yet? Feminism, Post-feminism and Domesticity'.

In: Joanne Hollows and Rachel Moseley, Eds. Feminism in Popular Culture. Oxford: Berg, 97-118.

Massumi, Brian. 1993. A User's Guide to Capitalism and Schizophrenia. Cambridge MA: The MIT Press.

Nelson, Carolyn, Christensen. 2000. Ed. A New Woman Reader. Peterborough: Broadview Press.

Perry, Gill. 1995. Women Artists and the Parisian Avant-Garde. Manchester: Manchester University Press.

Plummer, Keith. 2001. Documents of Life 2. London: Sage.

Pollock, Griselda. 1988. Vision and Difference: Femininity, Feminism and the Histories of Art.

London: Routledge. 
Probyn, Elspeth. 1993. Sexing the Self: Gendered Positions in Cultural Studies. London: Routledge.

Reed, Christopher. 1996. 'A Room of One's Own”: The Bloomsbury Group's Creation of a Modernist Domesticity'. In: Christopher Reed, Ed. Not at Home: The Suppression of Domesticity in Modern Art and Architecture. London: Thames and Hudson, 147-160.

Reed, Christopher. 2004. Bloomsbury Rooms: Modernism, Subculture and Domesticity. New Haven: Yale University Press.

Rose, Gillian. 1993. Feminism and Geography. The Limits of Geographical Knowledge. Cambridge: Polity Press.

Rothenstein, John. 1980. 'Foreword'. In: Noel Carrington: Carrington: Paintings, Drawings and Decorations. London: Thames and Hudson, 9-13.

Simons, Jon. 1995. Foucault and the Political. London: Routledge.

Stanley, Liz. 2004. The Epistolarium: On Theorizing Letters and Correspondences. Auto/Biography, 12 (3), 201-235.

Tamboukou, Maria. 2003 Women, Education, the Self: a Foucauldian perspective. Basingstoke: Palgrave, Macmillan.

Tamboukou, Maria. 2008. 'Re-imagining the narratable subject'. Qualitative Research, 8 (3), 283-292.

Tamboukou, Maria. 2009. 'Leaving the self, Nomadic passages in the memoir of a woman artist. Australian Feminist Studies, 24:61, 307-324.

Tamboukou, Maria . 2010a. In the Fold Between Power and Desire; Women Artists' Narratives. Newcastle-upon-Tyne: Cambridge Scholars Publishing.

Tamboukou, Maria. 2010b. Nomadic Narratives, Visual Forces: Gwen Fohn's Letters and Paintings. New York: Peter Lang.

Wolff, Janet. 1990. Feminine Sentences, Essays on Women and Culture. Cambridge: Polity Press.

Woolf, Virginia. 1945. A Room of One's Own, Harmondsworth: Penguin.

Woolf, Leonard. and Strachey, James. Eds. 1956. Virginia Woolf and Lytton Strachey Letters. New York: Harcourt, Brace and Company.

\footnotetext{
${ }^{1}$ Garnett 1975, 360.

2 There has been a rich scholarship around the people and activities of the Bloomsbury group. For an overview of the relevant bibliography, see Caws 1990, 211.

${ }^{3}$ See a collection of her paintings with themes taken form her houses in Hill 2000, 46, 48, 56, 57, 58, 61; for Tidmarsh Mill House and pages 90, 92, 95, 97 for Ham Spray House. For Mill at

Tidmarsh, c.1918, Private collection, see:

http://www3.flickr.com/photos/_fabio/66256424/in/set-1429437/

Other sites with Carrington's work: www.artcyclopedia.com/artists/carrington_dora.html.

${ }^{4}$ Garnett 1975, 361-2.

${ }^{5}$ HRC/B1/F.10/ DC Collection, Letters to Dorelia John, 1926-1928.
} 
${ }^{6}$ HRC/B.14/ F.1/ GB Collection, Letters from Carrington.

${ }^{7}$ HRC/B.1/ F.2/DC Collection, Letters to Noel Carrington

${ }^{8} \mathrm{HRC} / \mathrm{B} .1 / \mathrm{F} .6 / \mathrm{nd} /$ letters to Gertler

${ }^{9}$ HRG/B.10/F.4/GB Collection, Letters from Carrington, emphasis in the text.

${ }^{10}$ It actually took thirty-eight years after her death for an exhibition of her work as a whole to be held at the Upper Grosvenor Galleries in London, in 1979.

11 The archival work at Texas was funded by a small AHRC grant for which I am thankful.

12 What is particularly interesting about the files of the Harry Ransom Centre is that they include files with 'published letters'. In this way published and unpublished letters have actually created a continuum in my research archive.'

${ }^{13}$ Expanding the discussion of epistolary analytics goes well beyond the scope and limitations of this paper but I have written extensively about it. (See Tamboukou 2008, 2010b)

14 See, Conversations with Cézanne (Doran 2001, 112).

15 Garnett 1975, 236-237.

16 The figure of the New Woman emerged in the late nineteenth century to denote women's changing role in society. For an overview of the discussions around the New Woman, see Nelson 2000.

17 Eminent Victorians, 1918; Queen Victoria, 1921

${ }^{18}$ Garnett 1975, 152.

${ }^{19}$ HRC/B.1/ F.2/DC Collection, Letters to Noel Carrington.

${ }^{20} \mathrm{HRC} / \mathrm{B} .10 / \mathrm{F} .4 / \mathrm{GB}$ Collection, Letters from Carrington.

${ }^{21}$ Garnett 1975, 324-325.

22 HRC/B.11/F.3/GB Collection, Letters from Carrington.

${ }^{23}$ For a detailed discussion of the epistolary discourse of women artists, see Tamboukou, 2009, $2010 \mathrm{~b}$

${ }^{24}$ HRC/B.12/F.1/GB Collection, Letters from Carrington.

${ }^{25}$ HRC/B.10/F.4/GB Collection, Letters from Carrington.

${ }^{26}$ Garnett 1975, 191.

27 Letter to Strachey, August 1923 (Garnett 1975, 258-9)

${ }^{28}$ HRC/B.13/F.2/GB Collection, Letters from Carrington, emphasis in the text.

${ }^{29}$ As Hill notes, Tidmarsh Mill was funded by Oliver Strachey, Maynard Keynes, Harry Norton and Saxon-Sydney Turner. $(2000,47)$

30 Woolf and Strachey 1956, 88.

31 Garnett 1975, 413.

32 For an overview of this debate and discussion of the literature, see amongst others, Felski 2000, Giles 2004, Probyn 2005 and Hollows 2006.

${ }^{33}$ Lytton Strachey to Duncan Grant, 23 August 1909, cited in Reed (1996, 147)

${ }^{34}$ Garnett 1975, 21.

${ }^{35}$ HRC/B.1/ F. 6-9/ DG Collection, Letters to Gertler, emphasis in the text.

${ }^{36}$ Garnett 1975, 27.

${ }^{37}$ Ibid., 28

${ }^{38}$ HRC/B.10/F.8/ GB collection, Letters from Carrington, emphasis in the text.

${ }^{39}$ Garnett 1975, 434.

${ }^{40} \mathrm{HRC}$ /B.10/F.4/ GB collection, Letters from Carrington.

${ }^{41}$ Lines of flight, deterritorializations, becomings and striated and smooth spaces are concepts from Deleuze and Guattari's philosophy (1988). 'Striated' spaces are hierarchical, rule-intensive, strictly

bounded and confining, whereas 'smooth spaces' are open, dynamic and allow for transformations to occur. As a matter of fact, we experience the world as a continuum of striated and smooth spaces: there are always deterritorializations and lines of flight from striated to smooth 
spaces, but also reterritorializations and returns within striated spaces. See, Deleuze and Guattari, 1988, 474.

${ }^{42}$ For a review of feminist discussions around space, place and gender, see amongst others, Tamboukou 2003.

${ }^{43}$ BL/Add.65159/DC Partridge, her book, 1932, 74.

${ }^{44}$ HRC/B.11/F.2/ GB collection, Letters from Carrington.

${ }^{45}$ As I have discussed elsewhere in detail, askesis is central in Foucault's theorization of the technologies of the self and in women's reconfiguration of them in their auto/biographical narratives. See Tamboukou 2003.

${ }^{46}$ Letter to Strachey, August 1923 (Garnett 1975, 258-9)

47 See Tamboukou 2003, for an extended discussion of technologies of the female self'.

48 Garnett 1975, 341-2.

49 Cited in Hill 2000, 27.

${ }^{50}$ HRC/B.1/ F.2/DG Collection, Letters to Noel Carrington.

${ }^{51}$ HRG/B.1/ F.6/DG Collection, Letters to Gertler.

52 Ibid.

${ }^{53}$ HRC/B.11/F.4/ GB collection, Letters from Carrington.

54 Ibid.

55 There is in fact a rich body of literature around the fin-de-siecle artistic communities of Paris and women artists modes of existence within them. See amongst others, Perry, 1995; Pollock, 1988; Wolff, 1990.

56 For a detailed discussion of the theme of leaving in relation to women artists' narratives where the notion of the nomad is also elaborated, see Tamboukou 2009. 